\title{
Senior Editors' Note
}

The senior editors of International Labor and Working-Class History are proud to present our first issue devoted entirely to the field of African labor history. In recent years our publisher, Cambridge University Press, has noted an encouraging increase in our international readership, particularly in the Global South. We have intensified our efforts to bring greater regional balance to our issues, and most recently we noticed a spike in submissions on Africa. Our international outreach has benefitted from the addition of Marcel van der Linden, research director of the International Institute of Social History (IISH), Amsterdam, to our editorial board. He has been key to disseminating information about $I L W C H$, working the Institute's expansive network of labor history institutions on behalf of the journal. Our "calls for papers" are now distributed to scholars in areas that have been underrepresented in international publications on labor history, and as a result, we have been able to include a number of Africa-focused contributions in our thematic issues in recent years. ${ }^{1}$

After a period of considerable activity in African labor history in the 1970s and 1980s, there appeared to be a supplanting of historical scholarship by the social sciences. But recently we have noticed a surge in new types of historical studies - work that addresses gender, identity, culture, and forms of labor perhaps not traditionally classified as "work." At the same time, there is increased activity on the continent, including a number of conferences on African labor history. For example, in December 2011 the Faculté des Sciences de l'Éducation et de la Formation (FASTEF) of the Université Cheikh Anta Diop, Dakar, Senegal, hosted an international symposium, "Changes in the Cultural Patterns of Work in Africa-a Comparative Approach" in collaboration with the International Institute of Social History, Amsterdam. In January 2014 the University of Ghana at Legon, Humboldt University's International Research Center for "Work and Human Lifecycle in Global History" and ForcedLaborAfrica sponsored a conference in Ho, Ghana, "Pathways into Colonial (and Postcolonial?) Coercion: The creation and evolution of forced labor in Sub-Saharan Africa under Colonial Rule, 1890-1975." Additionally, in December 2013, the Africa regional office of the International Labour Organization held a workshop in Addis Ababa, Ethiopia, to produce a multivolume General Labor History of Africa for the organization's centenary celebration in 2019. Given all this activity, the ILWCH editorial board decided it was time to "test the waters," so to speak, and, for the first time, devote an entire issue to the field of African labor history. We are very pleased with the result and to see $I L W C H$ being considered a desirable publication outlet for scholars working on the frontiers of African labor history. 
$I L W C H$ is fortunate to have as guest editors for this issue our new board member, Franco Barchiesi, a historical sociologist who works on South Africa, and his colleague, Stefano Bellucci, Africa area coordinator for Amsterdam's International Institute of Social History. They both are directly involved in the current resurgence of African labor history. In this issue of $I L W C H$, they have brought together a series of articles with a chronological sweep from the precolonial to the postcolonial periods and a broad definition of labor, which includes both free (wage) labor and various forms of unfree labor-slavery, contract labor, the military, and domestic work. The articles deal with the creation of a working class, labor, African idioms of masculinity, seamen's response to the postcolonial context, missionaries' use of child labor, white South African workers and postapartheid ethnic politics, and the antislavery initiatives of European reformers confronting slavelike conditions in the early twentieth century. The issue also includes a review essay by Stephen Rockel (University of Toronto) that will introduce readers to new directions in the study of colonial Africa.

This issue will expose the $I L W C H$ readership to some of the new and exciting work being done on and about the continent. The masterful introduction is a comprehensive overview of the field as it has evolved over several decades, as well as a summary of the foci of the issue's contents. Barchiesi and Bellucci have curated a collection of scholarship on African labor that will familiarize our readers with the new directions and trajectories of the field. In addition to the historical articles, they also include two "Notes from the Field" that discuss current labor-related events in Egypt and South Africa. Hanan Sabea writes from Cairo of the decided government push against labor and social movements in the current political climate of Egypt. This note updates a report by Joel Beinin, published in 2011, "Workers and Egypt's January 25 Revolution," when it appeared that Egypt's workers saw real possibilities for creating revolutionary change. ${ }^{2}$ The second, by Bridget Kenny, is a detailed examination of the deteriorating labor conditions in low-paying retail jobs held largely by black African women in a subsidiary of South Africa's Mass Mart, a large-scale retailer, in which Walmart has recently purchased a share. It appears that the strategy of tightening control and declining wages was the ultimate goal of replacing the Afrikaner ${ }^{3}$ women who originally held these positions and tried to block black competition in the late 1960s. Moreover, Kenny notes another retail strategy of further immiserating the poor - the targeting of low-income consumer markets that will deepen the culture of debt.

In its entirety, this is an extraordinary issue that we hope will further increase the visibility of $I L W C H$ as a source of new scholarship on Africa.

ILWCH is also initiating a new system for the submission and review of articles called ScholarOne. From now on, proposals for articles, in the form of 500-word abstracts, should be uploaded at http://mc.manuscriptcentral.com/ ilwch

Finally, we are pleased to report that our next issue will continue our effort to expand coverage of regions of the Global South. Devoted exclusively to 
Indian labor history, it is being edited by $I L W C H$ Senior Editor Prasannan Parthasarathi.

\section{Carolyn Brown, Jennifer Klein and Prasannan Parthasarathi \\ Senior Editors}

\section{NOTES}

1. See Alan Mikhail, "Labor and Environment in Egypt since 1500," ILWCH 85 (2014): 10-32; Daniel Magaziner and Sean Jacobs, "Notes from Marikana, South Africa: The Platinum Miners' Strike, the Massacre, and the Struggle for Equivalence," ILWCH 83 (2013): 137-42; Franco Barchiesi, "How Far from Africa's Shore? A Response to Marcel van der Linden's Map for Global Labor History," ILWCH 82 (2012): 77-84; Gabrielle Hecht, "The Work of Invisibility: Radiation Hazards and Occupational Health in South African Uranium Production," ILWCH 81 (2012): 94-113; Michelle Moyd, "Making the Household, Making the State: Colonial Military Communities and Labor in German East Africa," ILWCH 80 (2011): 53-76.

2. ILWCH 80 (2011): 189-96.

3. See Danelle van Zyl-Hermann, "Baas or Klaas? Afrikaner Working-Class Responses to Transformation in South Africa, ca. 1977-2002" in this issue of ILWCH, pp. 142-158. 